\title{
Attieké street vendors: a potential source for dissemination of virulent strains of Staphylococcus aureus in consumers
}

\author{
Sylvie Mireille KOUAMÉ-SINA ${ }^{1 *}$, Yakoura K. OUATTARA ${ }^{3}$, Fernique KONAN $^{2}$, \\ David COULIBALY N'GOLO ${ }^{1}$, Kan Stephane KOUASSI ${ }^{1}$, \\ Solange N'GAZOA-KAKOU ${ }^{1}$ and Adjéhi DADIÉ ${ }^{3}$
}

${ }^{1}$ Platform of Molecular Biology, Pasteur Institute of Côte d'Ivoire, BP 490 Abidjan 01.

${ }^{2}$ National Reference Center for Antibiotics, Pasteur Institute of Côte d'Ivoire, BP 490 Abidjan 01.

${ }^{3}$ Nangui Abrogoua University, B.P 801, Abidjan 01, Côte d'Ivoire.

"Corresponding author; E-mail: kouamesylviemireille@yahoo.fr

\begin{abstract}
The Attiéké is a typical Ivorian side dish made from cassava pulp and more than $34 \%$ of households in Abidjan consume attiéké at least once a day with fish or meat. There is also a high consumption in street catering and before being served to customer, attieké is kneaded with hand by saleswomen in order to detach the granules. Our objective was to assess the presence of $S$. aureus on the hands of Attiéké vendors and investigate for their virulence factors and antibiotics resistance profile. S.aureus strains were recovered from fifty-four street vendors of Attiéké and screened by PCR to detected toxins genes (LukS, EtA and tst) and then tested for susceptibility against antibiotics by disc diffusion method. Of the 54 vendors, 42 (77.8\%) were found to be harboring S.aureus in their hands. The genes EtA, EtB and $t s t$ were detected respectively in $2.4 \%, 4.8 \%$ and $2.4 \%$ S. aureus strains. None of strains contained $L u k S$ gene. All the strains were methicillin-susceptible $S$. aureus and resistant to penicillin and $61.9 \%$ of strains were multiple drug resistant. A high prevalence of antibiotics resistance and the presence of virulent S.aureus strains among street vendors represent a potential health hazard for consumers of Attiéké.
\end{abstract}

(C) 2019 International Formulae Group. All rights reserved.

Keywords: Attieké, S. aureus, Staphylococcal toxins, food handler, Exfoliative toxins.

\section{INTRODUCTION}

The Attiéké is a typical Ivorian side dish made from cassava pulp (Manihot esculenta Crantz) that is a part of Côte d'Ivoire cuisine. It is cassava semolina fermented, partially dehydrated, steamed and agglomerated in appearance which is similar in texture to couscous (Gnagne et al., 2016; NI 484, 2013). In Abidjan, more than $34 \%$ of households consume Attiéké at least once a day with fish or meat (Assanvo et al., 2006; Djeni et al., 2011). There is also a high consumption of Attiéké in Abidjan streets due to the rapid urbanization and the lower cost of this dish. Several authors have reported the high microbial contamination of Attieké produced and marketed in the informal sector and not always respecting the good hygiene practices and conservation. Previous studies (Kouamé et al., 2013; Yobouet et al., 2016) have revealed the presence of faecal coliforms, Fusarium species, Bacillus cereus group and Staphylococcus aureus in Attiéké sold in Abidjan. The presence of these 
bacteria in food occurs frequently due to inappropriate manipulation of food by carriers of this microorganism. For food poisoning outbreaks, Staphylococcus aureus carriers in food handlers were described as the major source of contamination by epidemiological and molecular data. Staphylococcus aureus is considered as a normal flora or commensal of the skin and nasal cavities of humans and various animal species (Grema et al., 2015). Previous studies have shown that $20-50 \%$ of the human populations are often colonized with S. aureus (Mat et al., 2014; Mat et al., 2017). Humans, food animals, food contact surfaces, and tools or environments can serve as vehicles for the transfer of $S$. aureus to foods (Chao et al., 2015). Food handlers contribute to food safety, being potential sources of bacteria that cause foodborne diseases due to the introduction of pathogens during its processing, distribution and manipulation (Rall et al., 2010). Food is a suitable growth environment for toxinproducing bacteria such as Staphylococcus aureus, which is able to grow and express its virulence in a wide variety of foods (Normanno et al., 2005, 2007; Adams and Moss, 2008). This species is one of the pathogens responsible for foodborne disease outbreaks worldwide ( $\mathrm{Li}$ et al., 2015). Staphylococcal food poisoning is a major health problem (Kadariya et al., 2014) because $S$. aureus possesses an arsenal of virulence factors that contribute to evasion of host defenses. Important virulence factors implicated in the pathogenesis of $S$. aureus include staphylococcal enterotoxins (SEs), or enterotoxin-like proteins (SEl), exfoliative toxins, superantigen staphylococcal toxic shock syndrome toxin-1 (TSST-1), and Panton-Valentine Leucocidin (PVL), and other exoproteins are also responsible for particular clinical manifestations (Vancraeynest et al., 2006 ; Aung et al., 2017; vitale et al., 2018). As years pass by, S. aureus has developed resistance towards antibiotics, starting from penicillin, then methicillin and more recently towards vancomycin. The rise of drug-resistant virulent strains of Staphylococcus aureus, particularly methicillin-resistant S. aureus (MRSA) is a serious problem in the treatment and control of Staphylococcal infections. Methicillinresistant Staphylococci (MRS) cause hard-totreat infections. The most striking situation is that MRSA strains have emerged with concomitant resistance to many commonly used antibiotics of groups, aminoglycosides, macrolides, fluoroquinolones, chloramphenicol, and tetracycline (Kaur and Chate, 2015). MRSA can be easily transmitted from person to person either by direct contact with the person who is infected, a carrier or by touching contaminated things or substances. The carriage of enterotoxigenic $S$. aureus by food handlers is an important source of staphylococcal food contamination in restaurants and fast food outlets (Colombari et al., 2007). Therefore it is important to screen for $S$. aureus carriage among food handlers in order to ascertain the epidemiology, pattern of antibiotic susceptibility and to prevent possible food contamination by them that may result in food poisoning. This will also help develop preventive measures as well as treatment possibilities (Emeakaroha et al., 2017). Food handlers may constitute a reservoir of virulent strains of $S$. aureus and may be vehicles of their transmission to food. In fact, food poisoning outbreaks associated with post-process contamination of foods with S. aureus are in part the responsibility of food handlers who carry enterotoxigenic staphylococci in their nares or on their skin (Castro et al., 2016). The aim of this study was to determine the prevalence of $S$. aureus in hands of Attiéké street vendors and then investigated for their virulence genes and antibiotics resistance.

\section{MATERIALS AND METHODS Study area}

The study was carried out at Abidjan, a city on the southern Atlantic coast of Côte d'Ivoire, in West Africa. It is the economic capital and the country's major urban center. It is one of the areas of high production and consumption of Attiéké. The daily production of freshly Attiéké reaches over 100 tons for artisanal sector. Most of these attiéké are 
processed by small scale producers, thus making quality control difficult (Djeni et al., 2011). The annual consumption of attiéké was estimated to 450000 tons (Yobouet et al., 2016).

\section{Sample collection and bacterial isolation}

This study was conducted from October 2017 to march 2018 in two (2) sites of Yopougon a municipality of Abidjan: Adiopodoume and Lievre-rouge. Street retail attieké vendors were selected based on their willingness for participate to this study. In these street restaurants, the attieké dish is served with raw vegetables and fried fish on the roadside. The attieké before being served to consumer is kneaded with fingers (without gloves) by the vendor to detach the granules. A total of 54 vendors were selected in this study especially at Adiopodoume $(n=29)$ and Lievre-rouge $(n=25)$. Samples were collected from the hands of vendors according the imprint method described by Pittet et al., (1999). The imprint of the 5 fingertips of the vendor's dominant hand on Chapman plates was taken in the sales site of attieké. Fingertips were gently pressed for 5 seconds. As soon as possible (until 1 hour) after the sampling, Chapman plates were transported $\left(+4{ }^{\circ} \mathrm{C}\right)$ and incubated at $37^{\circ} \mathrm{C}$ for 24 hours in the laboratory. After incubation, suspect colonies (golden or yellow) showing the typical features of staphylococci were identified by standard microbiologic procedures including Gram staining, catalase activity, mannitol fermentation and the ability to coagulate rabbit plasma (Amini et al., 2012).

\section{Amplification of 16SrRNA, FemA, LukS, $E t A, E t B$ and $t$ st genes}

After Overnight culture of bacterial strains in Brain-Heart Infusion, cells were harvested at $12000 \mathrm{rpm}$ for $3 \mathrm{~min}$. Then, DNA was extracted by using Qiagen DNA isolation kit (Hilden, Germany) according to the manufacturer's instructions.

Genomic DNA was used as a template for polymerase chain reactions (PCR) amplification. According to modified methods of multiplex PCR previously described by Kacou et al. (2011), six genes were screened in two multiplex PCR. The first multiplex PCR was performed to identify the Staphylococcus genus (16S rRNA gene), to differentiate $S$. aureus from Coagulasenegative Staphylococci (CNS) (FemA gene), and to detect Panton-Valentine leukocidin toxin $(L u k S)$ genes simultaneously. This first PCR was performed in a final volume reaction of $25 \mu \mathrm{L}$ containing $9.75 \mu \mathrm{L}$ nuclease-free water (Ambion), $5 \mu \mathrm{L}$ PCR buffer (5X), 1.5 $\mu \mathrm{L}$ Magnesium Chloride $(\mathrm{MgCl} 2)(25 \mathrm{mM})$ (Promega Corporation, Madison, USA), 0.5 $\mu \mathrm{L}$ Deoxynucleotide Triphosphates (dNTPs) $(10 \mathrm{mM}), 0.5 \mu \mathrm{L}$ of each primer $(20 \mathrm{mM})$ (Table 1), $0.25 \mu \mathrm{L}$ Go Tag®G2 Flexi DNA polymerase $5 \mathrm{U} / \mu \mathrm{L}$ (Promega Corporation, Madison, USA) and $5 \mu \mathrm{L}$ of template DNA. The PCR method was performed according to the following program: initial denaturation (94 ${ }^{\circ} \mathrm{C}, 5$ minutes), 35 cycles each composed of initial denaturation $\left(94{ }^{\circ} \mathrm{C}, 30\right.$ seconds), primer annealing $\left(60{ }^{\circ} \mathrm{C}, 1\right.$ minute $)$ and extension $\left(72{ }^{\circ} \mathrm{C}, 1\right.$ minute) and a final extension $\left(72{ }^{\circ} \mathrm{C}, 5\right.$ minutes $)$. A previously known (Kacou et al., 2011) LukS gene positive $S$. aureus strain was used as a control strain. The second multiplex PCR was performed to detect staphylococcal exfoliative toxin genes (EtA and $E t B$ ) and staphylococcal toxic shock syndrome 1 (tst) gene in the same conditions than the first multiplex. The difference was the PCR program: initial denaturation ( $94{ }^{\circ} \mathrm{C}, 5$ minutes), 35 cycles each composed of initial denaturation $\left(94^{\circ} \mathrm{C}\right.$, 30 seconds), primer annealing $\left(55{ }^{\circ} \mathrm{C}, 1\right.$ minute) and extension $\left(72{ }^{\circ} \mathrm{C}, 1\right.$ minute $)$ and a final extension $\left(72{ }^{\circ} \mathrm{C}, 5\right.$ minutes $)$. All PCR amplification products were revealed on a gel Doc EZ® imager (Bio-Rad) after electrophoresis in $2 \%$ agarose gel containing Syber safe (Invitrogen).

\section{Antimicrobial susceptibility test}

The susceptibility testing was carried out by culturing $S$. aureus strains on MuellerHinton agar (Bio-rad, Marne-la-coquette, France) in accordance with the performance standards for antimicrobial susceptibility 
Table 1 : The primer sequences.

\begin{tabular}{|c|c|c|c|c|}
\hline Genes & Primers & Primer sequences (5'-3') & $\begin{array}{l}\text { Size of amplified } \\
\text { products (bp) }\end{array}$ & References \\
\hline $16 S$ & 16S rRNA-F & GCAAGCGTTATCCGGATTT & 597 & Al-Talib et al. \\
\hline$r R N A$ & 16S rRNA-R & CTTAATGATGGCAACTAAGC & & $(2009)$ \\
\hline \multirow[t]{2}{*}{ LukS } & LukS-F & CAGGAGGTAATGGTTCATTT & 151 & \\
\hline & LukS-R & ATGTCCAGACATTTTACCTAA & & \\
\hline \multirow[t]{2}{*}{ FemA } & FemA-F & CGATCCATATTTACCATATCA & 450 & \\
\hline & FemA-R & ATCACGCTCTTCGTTTAGTT & & \\
\hline \multirow[t]{2}{*}{ EtA } & etA-F & CTAGTGCATTTGTTATTCAAGACG & 119 & Becker et al. \\
\hline & etA-R & TGCATTGACACCATAGTACTTATTC & & $(1998)$ \\
\hline \multirow[t]{2}{*}{$E t B$} & etB-F & ACGGCTATATACATTCAATTCAATG & 262 & \\
\hline & etB-R & AAAGTTATTCATTTAATGCACTGTCTC & & \\
\hline \multirow[t]{2}{*}{ tst } & tst-F & AAG CCC TTT GTT GCT TGC G & 445 & \\
\hline & tst-R & ATC GAA CTT TGG CCC ATA CTT T & & \\
\hline
\end{tabular}

testing, recommended by the Committee of antibiogram of French Society of Microbiology (CA-SFM/EUCAST, 2016). Antibiotics used for susceptibility testing included penicillin $6 \mu \mathrm{g}$, cefoxitin $30 \mu \mathrm{g}$, ciprofloxacin $5 \mu \mathrm{g}$, ofloxacin $5 \mu \mathrm{g}$, norfloxacin $5 \mu \mathrm{g}$, kanamycin $30 \mu \mathrm{g}$, gentamicin $10 \mu \mathrm{g}$, tobramycin $10 \mu \mathrm{g}$, erythromycin $15 \mu \mathrm{g}$, clindamycin $2 \mu \mathrm{g}$, minocyclin $30 \mu \mathrm{g}$, tigecyclin $30 \mu \mathrm{g}$, tetracyclin $30 \mu \mathrm{g}$, chloramphenicol $30 \mu \mathrm{g}$, fosfomycin $10 \mu \mathrm{g}$, fusidic acid $10 \mu \mathrm{g}$, nitrofuran $100 \mu \mathrm{g}$ and rifampicin $5 \mu \mathrm{g}$. All antibiotics were obtained from Bio-rad. It should be indicated that the reference strain Staphylococcus aureus ATCC 29213 were used as positive-control and provided by the National Reference Center for Antibiotics, Pasteur Institute of Côte d'Ivoire.

\section{RESULTS}

Prevalence of $S$. aureus hand carriage among attieké vendors

All the 54 vendors of attieké in this study were female. S. aureus strains isolated were identified by Gram-positive cocci, catalase positivity, mannitol fermentation, coagulase production. However, strains that were Gram-positive cocci, catalase positive, and coagulase negative were considered as coagulase-negative Staphylococci. This phenotypic identification was confirmed by PCR results (Figure 1). Of the 54 vendors of attiéké, 48 (88.9\%) had Staphylococci spp in their hands. Among 48 Staphylococci spp isolated, 42 strains $(87.5 \%)$ were Staphylocccus aureus (16SRNA positive and femA positive) and 6 strains (12.5\%) were Coagulase-negative Staphylococci (16SRNA positive and $f e m A$ negative). The prevalence of $S$. aureus hand carriage in vendors of attieké was $77.8 \%$ (42/54).

\section{Staphylococci hand colonization associated with sites of sale}

The Staphylococci strains were isolated in the hands of vendors of Adiopodoume and both Lievre-rouge vendors. Prevalence of $S$. aureus colonization among attieké vendors of Adiopodoume was $75.8 \%(22 / 29)$ and $80 \%$ 
(20/25) among vendors of Lievre-rouge site (Table 2). There is no significant difference of the prevalence of S.aureus hand carriage between vendors of Adiopodoume and Lievrerouge $(\mathrm{P}=0,487 ; \mathrm{P}>0,05)$.

\section{Virulence genes detected among $S$. aureus strains}

Four S. aureus strains $(9.5 \%)$ carrying virulence genes (EtA,EtB and $t s t$ ) (Figure 2 and 3). EtB was the most prevalent gene in strains recovered from hands of attieké vendors. None Panton-Valentine Leukotoxinencoding gene $(L u k S)$ was detected. In $42 S$. aureus strains, genes encoding for Staphylococcal exfoliative toxins EtA, EtB and staphylococcal toxic shock syndrome 1 tst were detected in $2.4 \%$ (1/42), $4.8 \%$ (2/42) and $2.4 \%(1 / 42)$ of $S$. aureus strains respectively (Table 3 ). The majority of virulence genes was detected among hand $S$. aureus carriage by vendors of Lievre-rouge site (3/4).

\section{Antibiotics susceptibility of S.aureus strains isolated from vendors hands}

The result of the antimicrobial sensitivity pattern of $42 S$. aureus strains from hands of attieké vendors shows that, all strains $(100 \%)$ were susceptible to cefoxitin and gentamicin, but resistant to penicillin (Table 4). The frequency of strains resistant to fosfomycin, fusidic acid, tetracyclin, minocyclin, rifampicin, chloramphenicol, clindamycin and erytromycin was $78.6 \%$, $61.9 \%, 54.8 \%, 52.4 \%, 38.1 \%, 35.7 \%, 31 \%$ and $35.7 \%$ respectively. The lower rate of resistance was observed for ofloxacin (16.7\%), kanamycin (14.3\%), tobramycin (9.5\%), ciprofloxacin (9.5\%), nitrifuran $(7.1 \%)$ and tigecyclin (4.8\%). Multiple Drug Resistant (MDR) organisms are microorganisms resistant to three or more classes of microbial agents. In this study, $61.9 \%$ (26/42) of $S$. aureus strains carriage by food vendors were MDR.

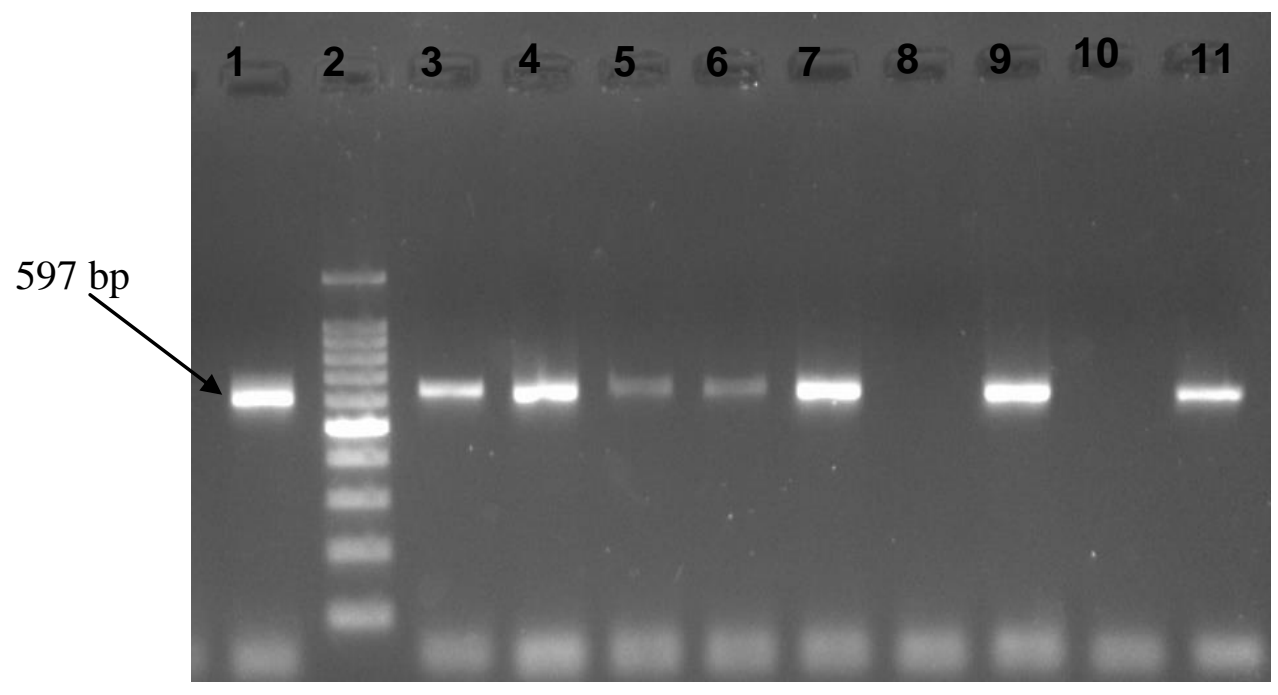

Figure 1: PCR amplification for detection of 16SRNA gene among S. aureus strains from attiéké vendors.

Lane 1: Positive control (16SRNA+); Lane 2: 100 bp DNA ladder; Lanes 3-7 and 9, 11: S. aureus strains positive for 16SRNA gene. 
Table 2: Prevalence of Staphylococci colonization among the attieké vendors by place of sale.

\begin{tabular}{lll}
\hline \multirow{2}{*}{$\begin{array}{l}\text { Attieké vendors by site } \\
(\mathbf{n}=\mathbf{5 4})\end{array}$} & \multicolumn{1}{c}{ Number of Staphylococci hands carriage } \\
\cline { 2 - 3 } & S. aureus $(\boldsymbol{\%})$ & CNS (\%) \\
\hline Adiopodoume $(\mathrm{n}=29)$ & $22(75.8 \%)$ & $5(17.2 \%)$ \\
Lievre-rouge $(\mathrm{n}=25)$ & $20(80 \%)$ & $1(4 \%)$ \\
\hline
\end{tabular}

CNS : Coagulase-negative Staphylococci.

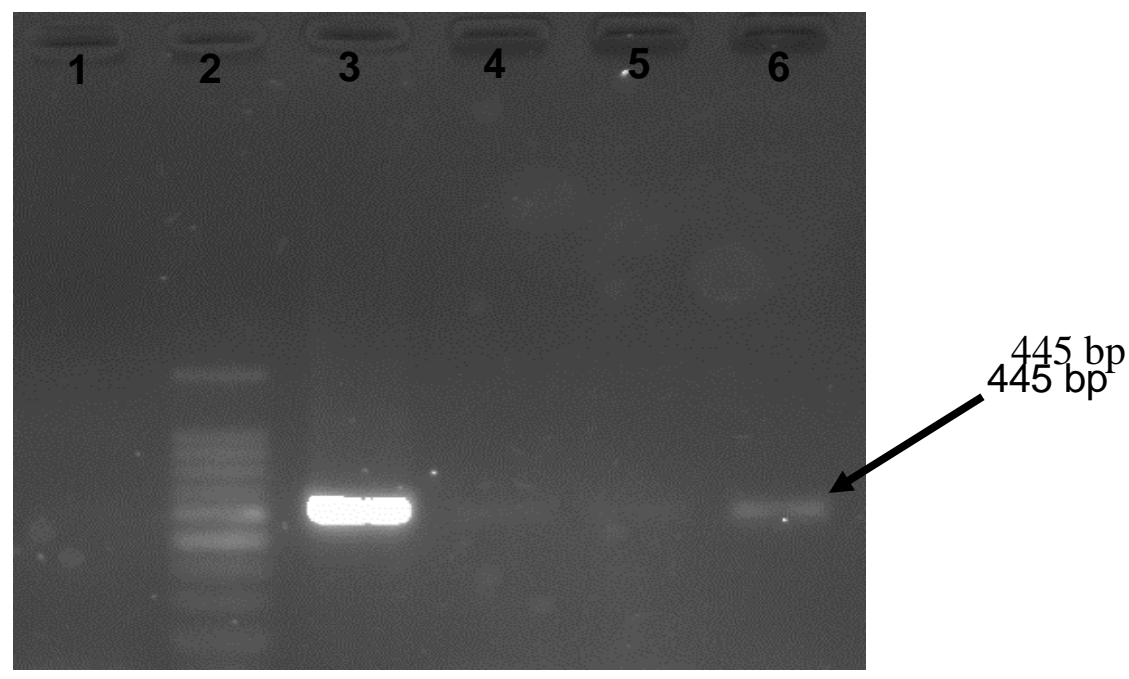

Figure 2: Electrophoresis result of $t$ st gene.

Lane 1: Negative control (tst-); lane 2: 100 bp DNA marker; lane 3: Positive control (tst+) ; lanes 6: S. aureus strains positive for $t s t$ gene.
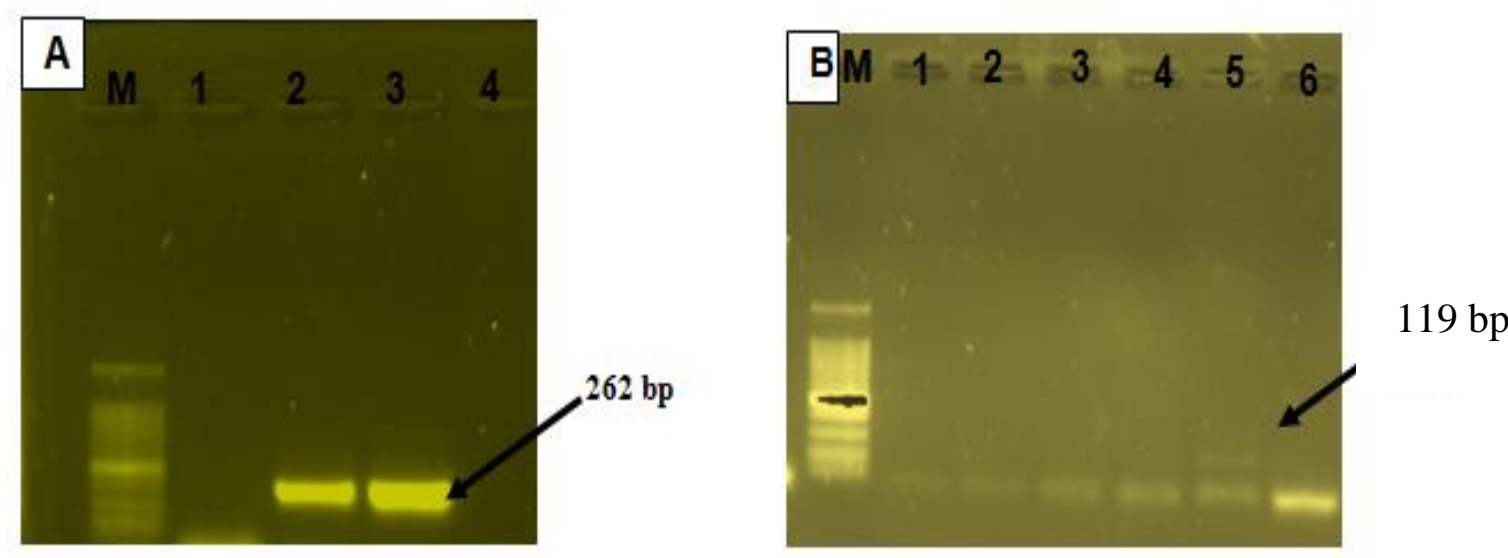

Figure 3 (A \& B): Electrophoresis result of $E t A$ and $E t B$ genes.

(A): Lane M: 100 bp DNA marker; Lanes 2-3: S. aureus strains positive for EtB gene; (B): Lane M: 100 bp DNA marker; Lanes 5: S. aureus strain positive for EtA gene. 
Table 3: Virulence genes detected among hand S.aureus strains.

\begin{tabular}{ccccc}
\hline \multirow{2}{*}{ Sites } & \multicolumn{4}{c}{ Number of virulence genes positive $\boldsymbol{S}$. aureus } \\
\cline { 2 - 5 } & $\boldsymbol{L} \boldsymbol{u} \boldsymbol{k} \boldsymbol{E}$ & $\boldsymbol{E} \boldsymbol{A}$ & $\boldsymbol{E t B}$ & tst \\
\hline Adiopodoume Strains & 0 & 0 & 1 & 0 \\
Lievre-rouge Strains & 0 & 1 & 1 & 1 \\
\hline \multicolumn{1}{c}{ Total (n=42) } & 0 & $1(2.4 \%)$ & $2(4.8 \%)$ & $1(2.4 \%)$ \\
\hline
\end{tabular}

Table 4: Antibiotics resistance of $S$. aureus strains recovered from hands of food vendors.

\begin{tabular}{lcc}
\hline Antibiotics & \multicolumn{2}{c}{ Number (\%) of resistant strains } \\
\cline { 2 - 3 } & Resistance $(\mathbf{n}=\mathbf{4 2})$ & Percentage \% \\
\hline Penicillin & 42 & 100 \\
Cefoxitin & 0 & 0 \\
Ciprofloxacin & 4 & 9.5 \\
Ofloxacin & 7 & 16.7 \\
Norfloxacin & 3 & 7.1 \\
Kanamycin & 6 & 14.3 \\
Gentamicin & 0 & 0 \\
Tobramycin & 4 & 9.5 \\
Erytromycin & 15 & 35.7 \\
Clindamycin & 13 & 31 \\
Minocyclin & 22 & 52.4 \\
Tigecyclin & 2 & 4.8 \\
Tetracyclin & 23 & 54.8 \\
Chloramphenicol & 15 & 35.7 \\
Fosfomycin & 33 & 78.6 \\
Fusidic acid & 26 & 61.9 \\
Nitrofuran & 3 & 7.1 \\
Rifampicin & 16 & 38.1 \\
\hline
\end{tabular}

\section{DISCUSSION}

Food handler may be a vector of foodborne disease spreading, due to inadequate personal hygiene or cross contamination (Bass et al., 2006). In our study, the carriage of potential pathogens in the hands of attieké vendors was $88.9 \%$ out of which $87.5 \%$ was $\mathrm{S}$. aureus and $12.5 \%$ was Coagulase-negative Staphylococci. In our study, the carriage of potential pathogens in the hands of attieké vendors was $88.9 \%$ out of which $87.5 \%$ was $S$. aureus and $12.5 \%$ was Coagulase-negative Staphylococci. Our findings are in line with those of several authors who have studied the presence of $S$. aureus in the hands of food handlers. Previous study conducted by Djeni et al. (2014) showed the highest level of contamination of attieké handlers (producers) by S.aureus in Abidjan (60\%), Dabou (73.6\%) and Jacqueville 
(93.3\%). Various species such as S. aureus, Klebsiella pneumoniae, Enterobacter agglomerans, Citrobacter youngae, Klebsiella oxytoca and Citrobacter freundi were isolated with high loads in this study. In a food company in Portugal (Castro et al., 2016) a lower prevalence of $S$. aureus was found on the hands $(11.1 \% ; 18 / 162)$ of food handlers. However, our rat is lower than those reported from Woh et al., (2017) among food handlers in Malaysia where $63.4 \%$ of hand swabs tested were positive for Staphylococcus aureus (Woh et al., 2017). Staphylococcus aureus was the predominant bacteria isolated from fingernail specimens (46\%; 63/137), among food handlers in the north of Iran (Nasrolahei et al., 2017). In addition, a previous studies (Djeni et al., 2011 ; Kouamé et al., 2013) conducted on attiéké marketed in Côte d'Ivoire reported a contamination by Bacillus subtilis, Bacillus cereus, Staphylococcus aureus, Citrobacter freundi, Enterobacter amnigenus, Citrobacter youngae, Enterobacter aerogenes, Klebsiella pneumoniae, Serratia marcescens, Enterobacter agglomerans and Klebsiella oxytoca. The presence of such microorganisms in attiéké samples could be due to an after steaming contamination by the contact of the product with air, the product handling and the plastic bag used and lake of hygiene practices during packaging, the use of unhygienic utensils but also by poor personal hygiene of attiéké handlers. A study carried out by Attien et al., (2014) on meat sold in Abidjan streets, showed the link between food contamination by S. aureus $(19.79 \%)$ and handlers or the unsterile containers. Moreover, there is no significant difference between prevalence of S.aureus hand carriage in the 2 sites of sampling (Adiopodoume and Lievrerouge). In the two sites, the street vendors had the same bad hygiene practices. During the sale, saleswomen use hands to serve customers. They do not wash their hands before and after serving customers and use an unhygienic cotton towel to wipe their hands. Indeed, the places of attieké sale of the 2 sites (Adiopodoume and Lievre-rouge) are located near the roads, in an environment influenced by pollution and heavily overloaded by fumes and exhaust gases from vehicles. The sellers of the Lievre-rouge site are located near a very busy market frequented by the population of Yopougon, with open gutter, poultry sales areas, cuts of beef and mutton and chickens. The majority of these vendors are close with other types of activity. Some attiéké sellers are installed right next to garbages and sell practically in the open air. In fact, food poisoning outbreaks associated with post-process contamination of foods with $S$. aureus are in part there sponsibility of food handlers who carry enterotoxigenic staphylococci in their nares or on theirs kin (Lues et al., 2007). With regard to virulence genes, the prevalences of EtA, EtB and tst genes among S.aureus were low (2.4\%, $4.48 \%$, and $2.4 \%$ respectively). In the study conducted by Argudín et al. (2012), in Spain, S.aureus isolated from foods and food handlers contained exfoliatin genes EtA (6.5\%), EtB (3.2\%) and tst gene (25.8\%) with prevalence higher than those detected in our study. tst genes have been previously (Castro et al., 2016) detected in S. aureus isolates recovered from food handlers, in higher percentage $(8.7 \%)$ than in our study. The detection of tst gene among hand of vendors is a major hazard to costumers, because this gene was the first marker identified for Staphylococcal toxic shock syndrome (TSS), which is anacute and potentially fatal illness that is characterized by a high fever, diffuse erythematous rash, desquamation of the skin one to two weeks afteronset (if not fatal before this time) et hypotension (Grumann et al., 2014). Several studies have revealed exfoliative toxin production by $S$. aureus strains isolated from foods sold in the streets. Sina et al. (2011) have detected S. aureus producing exfoliative A toxin (EtA) from food handled such as Macaroni (8.33\%), salad (17.65\%), bean $(22.2 \%)$, sold on the streets of Cotonou in Benin. Exfoliative toxins (also known as "epidermolytic" toxins) are responsible for the clinical manifestation of staphylococcal scalded skin syndrome. It is primarily characterized by skin exfoliation, early with fever, malaise, lethargy, and poor feeding. These symptoms are followed by an erythematous rash and the formation of large, fragile, fluid-filled blisters. (Bukowski et al, 2010). The prevalence of $E t A$ does not differ significantly among methicillin-resistant (MRSA) and methicillin-susceptible (MSSA) 
strains. The presence of these toxins genes among isolates in the Abidjan food vendors represents a potential health hazard for consumers of Attieké. Antimicrobial susceptibility of isolates shows that all the isolated $S$. aureus were susceptible to cefoxitin and gentamicin, but resistant to penicillin. The strains susceptible to cefoxitin were classified as those strains methicillinsusceptible. In this study, $100 \%$ of S. aureus strains were methicillin-susceptible $S$. aureus (MSSA). The frequency of others antibiotics resistance among $S$. aureus isolated in this study was ranging from $4.8 \%$ to $78.6 \%$ and $61.9 \%$ of strains were MDR. According to Udo et al. (2009), food handlers represent a section of the healthy population in the community, and the detection of high prevalence of antibiotic resistance in $S$. aureus isolated from them also highlights the growing problem of antibiotic resistance in the community.

\section{Conclusion}

Street food vending has become an important public health issue and a great concern to countries of sub-Saharan Africa as Côte d'Ivoire, due to widespread food borne diseases, due to the mushrooming of wayside food vendors who lack an adequate understanding of the basic food safety. This study showed the presence of $S$. aureus carried several virulence genes and resistant to antibiotics in food handlers. The presence of these strains in the food chain poses a threat to public health, since the strains were from the healthy vendors and deserves further attention. Adherence to strict hand washing protocols before and after touching the food will definitely bring down the carriage of toxinogenic $S$. aureus in these vendors there by bringing down its infections rates in consumers.

\section{COMPETING INTERESTS}

Authors disclose any commercial associations that might create a conflict of interest in connection with this manuscript.

\section{AUTHORS' CONTRIBUTIONS}

SMK-S is the instigator of this work and oversaw the overall work and the manuscript writing. OK has carried out laboratory tests and data management; FK has carried out antibiotics susceptibility tests; DCN provided guidance in laboratory analysis and manuscript editing. KSK, SN-K and $\mathrm{AD}$ have participated in the manuscript correction and data analysis.

\section{ACKNOWLEDGEMENTS}

Authors are grateful to staff of Department of Bacteriology, Plateform of Molecular Biology and National Reference Center for Antibiotics of Pasteur Institute of Côte d'Ivoire for their cooperation while carrying out this work.

\section{REFERENCES}

Adams MR, Moss MO. 2008. Bacterial agents of foodborne illness. Staphylococcus aureus. In Food Microbiology (3rd edition). Royal Society of Chemistry: Cambridge; 252-256.

Amini R, Abdulamir AS, Ling BP, Jahanshiri F, Hematian A, Zargar M, Sekawi Z, Jalilian FA. 2012. Isolation and identification of methicillin-resistant Staphylococcus aureus from keys of college students using different detection methods. Br. Biotechnol. J., 2(1): 13-25.

Assanvo JB, Agbo GN, Behi YEN, Coulin P, Farah Z. 2006. Microflora of traditional starter made from cassava for "Attiéké" production in Dabou (Côte d'Ivoire). Food Control, 17(1): 37-41. DOI: https://doi.org/10.1016/j.foodcont.2004.0 8.006 .

Attien P, Sina H, Moussaoui W, Zimmermann-Meisse G, Dadié T, Keller D, Riegel P, Edoh V, Kotchoni SO, Djè M, Prévost G, Baba-Moussa L. 2014. Mass Spectrometry and Multiplex Antigen Assays to Assess Microbial Quality and Toxin Production of Staphylococcus aureus Strains Isolated from Clinical and Food Samples. BioMed. Res. Int., 485620: 8 DOI: http://dx.doi.org/10.1155/2014/485 620

Aung MS, San T, Aye MM, Mya S, Maw WW, Zan KN, Htut WHW, Kawaguchiya M, Urushibara N, Kobayashi N. 2017. Prevalence and Genetic Characteristics of Staphylococcus aureus and 
Staphylococcus argenteus Isolates Harboring Panton-Valentine Leukocidin, Enterotoxins, and TSST-1 Genes from Food Handlers in Myanmar. Toxins, 2017(9): 241.2 DOI: 10.3390/toxins 9080241

Bass M, Ersun AS, Kivanç G. 2006. The evaluation of food hygiene knowledge, and practices of food handlers in food businesses in Turkey. Food Control, 17(4): 317-322. DOI: https://doi.org/10.1016/j.foodcont.2004.1 1.006

Bukowski M, Wladyka B, Dubin G. 2010. Exfoliative Toxins of Staphylococcus aureus. Toxins, 2(5): 1148-1165. DOI: https://doi.org/10.3390/toxins2051148

Chao G, Bao G, Cao Y, Yan W, Wang Y, Zhang X, Zhou L, Wu Y. 2015. Prevalence and diversity of enterotoxin genes with genetic background of Staphylococcus aureus isolates from different origins in China. Int. J. Food Microbiol., 211: 142-147. DOI: https://doi.org/10.1016/j.ijfoodmicro.201 5.07.018

Colombari V, Mayer MDB, Laicini ZM, Mamizuka E, Franco BDGM, Destro MT, Landgraf M. 2007. Foodborne Outbreak Caused by Staphylococcus aureus: Phenotypic and Genotypic Characterization of Strains of Food and Human Sources. J. Food Prot., 70(2): 489-493.

DOI:

https://doi.org/10.4315/0362-028X70.2.489

Committee of antibiogram of French Society of Microbiology (CA-SFM) /European Committee on Antimicrobial Susceptibility Testing (EUCAST). Recommandations.Version 1.0 February 2016. CA-SFM/ EUCAST.

Djeni NT, Kouame KA, Traore Y, Nevry KR, Dje KM. 2014. Assessment of knowledge, attitudes and practices of food handlers in Attieke production units in relation to food hygiene and safety in Cote d'Ivoire in 2012. Food and Nutrition Sciences, 5(10): 896-904. DOI: http://dx.doi.org/10.4236/fns.2014.51009 9

Djeni NT, N'Guessan KF, Toka DM, Kouame KA, Dje KM. 2011. Quality of attiéké (a fermented cassava product) from the three main processing zones in Cote d'Ivoire. Food Res. Int., 44: 410-416. DOI:10.1016/j.foodres.2010.09.032

Emeakaroha MC, Nkwocha IG, Adieze NC, Adieze IE. 2017. Antimicrobial susceptibility pattern of Staphylococcus aureus, and their nasal and throat carriage among food handlers at the Federal University of Technology, Owerri Nigeria. Int. J. Biomol. \& Biomed., 6(3) : 1-7.

Gnagne AAGB, Koffi KE, Assanvo BJ, Soro S. 2016. Influences de la congélation et du séchage de l'attiéké sur ses caractéristiques physico-chimiques et organoleptiques. Int. J. Biol. Chem. Sci., 10(2): $\quad 808-819 . \quad$ DOI: http://dx.doi.org/10.4314/ijbcs.v10i2.29

Grumann D, Nübel U, Bröker BM. 2014. Staphylococcus aureus toxins- their functions and genetics. Infect. Genet. Evol., 21: 583-92. DOI: 10.1016/j.meegid.2013.03.013

Kacou NA, Koffi KS, Ekaza E, KouaméElogne C, Anne BJC, Dosso M. 2011. Staphylococcus aureus infection and virulence genes in Abidjan (Côte d'Ivoire). Eur. J. Sci. Res., 52(3): 339344.

Kaur DC, Chate SS. 2015. Study of Antibiotic Resistance Pattern in Methicillin Resistant Staphylococcus Aureus with Special Reference to Newer Antibiotic. J. Glob. Infect. Dis., 7(2):78-84. DOI: 10.4103/0974-777X.157245

Kouame AK, Djeni TN, N'Guessan FK, Dje KM. 2013. Postprocessing microflora of commercial attiéké (a fermented cassava product) produced in the south of Cote d'Ivoire. Lett. Appl. Microbiol., 56 (1): 44-50.

DOI: https://doi.org/10.1111/lam.12014

Li Y, Zhao R, Zhang X, Han Q, Qian X, Gu G, Shi J, Xu J. 2015. Prevalence of enterotoxin genes and spa genotypes of methicillin-resistant Staphylococcus aureus from a tertiary care hospital in China. J. Clin. Diagn. Res., 9(5):11-14. DOI:10.7860/JCDR/2015/12090.5990.

Lues JFR, Van Tonder I. 2007. The occurrence of indicator bacteria on hands and aprons of food handlers in the 
delicatessensections of a retail group. Food Control, 18: 326-32. DOI:https://doi.org/10.1016/j.foodcont.2 005.10.010

Mat AN, Hamid AAB, Pung HP, Abdul Ra-fee PA, Yahya FA, Amin Nordin S, Neela V, Suhaili Z, Mohd DMN. 2014. Staphylococcus aureus infection risk in a population of health sciences students at a public university. Iran J. Public Health, 43(3): 112-126. DOI: http://ijph.tums.ac.ir

Mat Azis N, Pung HP, Rachman ARA, Nordin SA, Sarchio SNE, Suhaili Z, Desa MNM. 2017. A persistent antimicrobial resistance pattern and limited methicillin-resistance-associated genotype in a short-term Staphylococcus aureus carriage isolated from a student population. J. Infect. Public Health, 10(2): 156-164. DOI: 10.1016/j.jiph.2016.02.013.

Normes Ivoiriennes (NI) 484. 2013. Attiéké Spécification. Côte d'Ivoire Normalisation (1ere Edition). Normes Ivoiriennes, $5 \mathrm{p}$.

Normanno G, Firinu A, Virgilio S, Mula G, Dambrosio A, Poggiu A, Decastelli L, Mioni R, Scuota S, Bolzoni G, Di Giannatale E, Salinetti AP, La Salandra G, Bartoli M, Zuccon F, Pirino T, Sias S, Parisi A, Quaglia NC, Celano GV. 2005. Coagulase-positive Staphylococci and Staphylococcus aureus in food products marketed in Italy. Int. J. Food Microbiol., 98(1): 73-79. DOI: https://doi.org/10.1016/j.ijfoodmicro.200 4.05 .008

Normanno G1, La Salandra G, Dambrosio A, Quaglia NC, Corrente M, Parisi A, Santagada G, Firinu A, Crisetti E, Celano GV. 2007. Occurrence, characterization and antimicrobial resistance of enterotoxigenic Staphylococcus aureus isolated from meat and dairy products. Int. J. Food Microbiol., 115: 290-296. DOI:10.1016/j.ijfoodmicro.2006.10.049
Rall VLM, Sforcin JM, Augustini VCM, Watanabe MT, Fernan-des Jr A, Rall R, M.G. Silva MG, Araújo Jr.JP. 2010. Detection of enterotoxin genes ofStaphylococcus sp. isolated from nasal cavities and handsof food handlers. Braz. J. Microbiol., 41: 59-65. DOI: 10.1590/S1517-838220100001000011

Sina H, Baba-Moussa F, Kayodé AP, Noumavo PA, Sezan A, Hounhouigan JD, Kotchon SO, Prévost G, BabaMoussa L. 2011. Characterization of Staphylococcus aureus isolated from street foods: Toxin profile and prevalence of antibiotic resistance. $J$. Appl. Biosci., 46: 3133-3143.

Udo EE, Al-Mufti S, Albert MJ. 2009. The prevalence of antimicrobial resistance and carriage of virulence genes in Staphylococcus aureus isolated from food handlers in Kuwait city restaurants. BMC Res. Notes. 16(2):108. DOI: 10.1186/1756-0500-2-108.

Vancraeynest D, Hermans K, Haesebrouck F. 2006. Prevalence of genes encoding exfoliative toxins, leucotoxins and superantigens among high and low virulence rabbit Staphylococcus aureus strains. Vet. Microbiol., 117(2-4): 211218. DOI: 10.1016/j.vetmic.2006.05.009

Vitale M, Gaglio S, Galluzzo P, Cascone G, Piraino C, Lo Presti VD M, Alduina R. 2018. Antibiotic resistance profiling, analysis of virulence aspects and molecular genotyping of Staphylococcus aureus isolated in Sicily, Italy. Foodborne Pathog. Dis., 15(3): 177-185. DOI: 10.1089/fpd.2017.2338

Yobouet BA, Dadié A, Traoré SG, Djè KM, Bonfoh B. 2016. Contamination par Bacillus cereus de l'attiéké produit dans le secteur informel au sud de la Côte d'Ivoire et gestion du risque par le réchauffage hydrothermique. Int. J. Innov. Appl. Studies, 15(3): 637-654. 